\title{
Chapter 32 \\ Preliminary Seismic Deformation \\ and Soil-Structure Interaction Evaluations \\ of a Caisson-Supported Marine Terminal \\ Wharf Retaining and Founded \\ on Liquefiable Soils
}

\section{Arul K. Arulmoli}

\begin{abstract}
The seismic deformation and soil-structure interaction analyses completed to date (i.e., preliminary design) for the project would benefit from more rigorous validation and calibration of the constitutive models and numerical procedures used in future analyses. The results from the Liquefaction Experiments and Analysis Project (LEAP) are expected to benefit future phases of the project (i.e., detailed design).
\end{abstract}

\subsection{Thesis Statement}

The seismic deformation and soil-structure interaction analyses completed to date (i.e., preliminary design) for the project would benefit from more rigorous validation and calibration of the constitutive models and numerical procedures used in future analyses. The results from the Liquefaction Experiments and Analysis Project (LEAP) are expected to benefit future phases of the project (i.e., detailed design).

\subsection{Essay}

The Port of Vancouver (Port) is proposing to build a new marine terminal in Delta, British Columbia, Canada. The project calls for a caisson-supported wharf founded on potentially liquefiable foundation soils and retaining soils that are also potentially liquefiable. Soils immediately below and behind the caisson will be replaced with materials that will be densified after placement. The total retained height of the fill exceeds $25 \mathrm{~m}$.

\footnotetext{
A. K. Arulmoli ( $\square)$

Earth Mechanics, Inc., Fountain Valley, CA, USA

e-mail: arulmoli@earthmech.com 
The wharf will be designed to the most current seismic design requirements: i.e., three levels of earthquake ground motions (ASCE 2014). The wharf performance requirements for the three levels of earthquake limit lateral displacements at the base and top of the caisson (i.e., horizontal displacements and rotations are limited).

As the Port's Owner's Engineer (OE), the OE team performed preliminary seismic evaluations to develop initial optimum wharf configuration meeting the lateral displacement requirements. Initial evaluations included uncoupled geotechnical and structural analyses. Simplified lateral seismic deformation evaluations using available procedures (Bray and Travasarou 2007; Transportation Research Board 2008) and pseudo-static structural analysis using the computer program SAP2000 (Computers, and Structures, Inc. 2013) were completed to develop the initial wharf configuration. Seismic soil-structure interaction evaluations were performed for this configuration using the finite difference computer program FLAC (Itasca Consulting Group 2011) and using two constitutive models for sandy soils, UBCSAND (Beaty and Byrne 2011) and PM4SAND (Boulanger and Ziotopoulou 2015).

Significant differences were noted between the results from the UBCSAND and PM4SAND constitutive models. Since there was no available data on past performance of caissons in liquefiable soils from well-documented case histories or experiments, it was a challenge to reconcile these differences. The OE team members used their collective experience and judgment to develop the preliminary wharf configuration that could be refined during the subsequent detailed design phase with additional analyses.

In conclusion, the seismic deformation and soil-structure interaction analyses completed by the OE team to date would benefit from more rigorous validation and calibration of the analytical models, especially for adequately predicting liquefaction triggering, post-liquefaction soil strengths, and capturing post-liquefaction behavior of retaining structures in liquefiable soils. It is the author's hope that the Liquefaction Experiments and Analysis Project (LEAP) would include experiments using waterfront earth-retaining structures as well as evaluation of soil-structure interaction in liquefied soils (Kutter et al. 2014), which is expected to benefit the project during its future design phases.

Acknowledgement This abstract is based on the project that is funded by the Port of Vancouver. The Owner's Engineer team is led by Moffat \& Nichol and supported by Stantec and Earth Mechanics, Inc.

\section{References}

ASCE 61-14. (2014). Seismic design of piers and wharves. American Society of Civil Engineering (ASCE) Standard.

Beaty, M. H., \& Byrne, P. M. (2011). UBCSAND Constitutive Model, Version 904aR. Documentation Report on Itasca UDM Website, February.

Boulanger, R. W., \& Ziotopoulou, K. (2015). PM4Sand (Version 3): A sand plasticity model for earthquake engineering applications. Technical Report No. UCD/CGM-15/xx, Center for 
Geotechnical Modeling. Department of Civil and Environmental Engineering, University of California, Davis, CA.

Bray, J. D., \& Travasarou, T. (2007). Simplified procedure for estimating earthquake-induced deviatoric slope displacements. Journal of Geotechnical and Geoenvironmental Engineering, ASCE, 133(4), 381-392.

Computers \& Structures, Inc. (2013). SAP2000 v15.2.1.

Itasca Consulting Group. (2011). Fast Lagrangian analysis of continua. FLAC Version 7.0.

Kutter, B. L., Manzari, M. T., Zeghal, M., Zhou, Y. G., \& Armstrong, R. J. (2014). Proposed outline for LEAP verification and validation processes. In Proceedings of the Fourth International Conference on Geotechnical Engineering for Disaster Mitigation and Rehabilitation. Kyoto: Kyoto University.

Transportation Research Board. (2008). Seismic analysis and design of retaining walls, buried structures, slopes, and embankments. In National Cooperative Highway Research Program Report 611, Project 12-70, Washington, DC.

Open Access This chapter is licensed under the terms of the Creative Commons Attribution 4.0 International License (http://creativecommons.org/licenses/by/4.0/), which permits use, sharing, adaptation, distribution and reproduction in any medium or format, as long as you give appropriate credit to the original author(s) and the source, provide a link to the Creative Commons license and indicate if changes were made.

The images or other third party material in this chapter are included in the chapter's Creative Commons license, unless indicated otherwise in a credit line to the material. If material is not included in the chapter's Creative Commons license and your intended use is not permitted by statutory regulation or exceeds the permitted use, you will need to obtain permission directly from the copyright holder. 